\title{
COMPETITIVE ADVANTAGE IN SMALL AND MEDIUM ENTERPRISES (SMEs): A SYSTEMATIC MAPPING STUDY
}

\author{
*Meyzi Heriyanto ${ }^{1}$, Achmad Fajri Febrian ${ }^{2}$, Meilan Sugiarto ${ }^{3}$, Tito Handoko ${ }^{4}$, Syofian $^{5}$ \\ ${ }^{1}$ Department of Business Administration, Universitas Riau, Pekanbaru, Indonesia. \\ E-mail addressmeyzi.heriyanto@lecturer.unri.ac.id \\ ${ }^{2}$ Department of Business Administration, Universitas Riau, Pekanbaru, Indonesia. \\ E-mail address achmad.fajri@lecturer.unri.ac.id \\ ${ }^{3}$ Department of Business Administration, UPN Veteran, Yogyakarta, Indonesia. \\ E-mail address meilan.sugiarto@upnyk.ac.id \\ ${ }^{4}$ Department of Government Studies, Universitas Riau, Pekanbaru, Indonesia. \\ E-mail address tito.handoko@lecturer.unri.ac.id \\ ${ }^{5}$ Department Of Public Administration, Universitas Riau, Pekanbaru, Indonesia \\ E-mail address syofian@lecturer.unri.ac.id
}

Received 3009 2020; Accepted 04112020

\begin{abstract}
Small and medium-sized enterprises (SMEs) is likely to have an advantage over competitors due to their strategic plans. Meanwhile, some of the strategic factors considered important to have a competitive advantage include human resource development, knowledge management, and Information and Communication Technology. They have been found to build and sustain a dominant position for rivals, but there is a need to consider the state of the art of competitive advantage by entrepreneurs or academics. Therefore, this study aimed to classify and identify scientific publications as well as to carry out a thematic review of recent literature to provide a comprehensive and thorough view of the competitive advantage in SMEs. This included the use of the Systematic Mapping Study (SMS) to review scientific articles related to competitive advantage depending on the focus, locus, and type of study. The results of this mapping are expected to contribute to both researchers and practitioners in determining the research focus gap and the next novelty of competitive advantage research. Thus, this study classified competitive advantage based on the overview of previous research topics and trends.
\end{abstract}

Key words: competitive advantage, literature review, small and medium enterprises JEL Codes: L81, G29, D12, D01, L83.

\section{Introduction}

Small and Medium Enterprises (SMEs) contribute to the job market, have a positive impact on Indonesian society, and campaign to help create economic stability to ensure survival although other industries remain impacted by the global financial crisis in the 21st century (Febrian, Maulina, \& Purnomo, 2018; Maslakhah, 2017; Utama \& Darwanto, 2013).
Moreover, COVID-19 has been observed to be one of the reasons inhibiting the small and medium-sized enterprises development in 2020 which has previously been projected by the Indonesian Ministry of Finance (2020), to contribute $30.2 \%$ to the country's economy in 2024 and $61 \%$ to GDP in 2020 and $65 \%$ in 2024 while the entrepreneurial ratio was targeted to be $3.55 \%$ and $4 \%$ respectively.

Copyright (C) 2021 Author(s), published by Vytautas Magnus University. This is an open access article distributed under the terms of the Creative Commons Attribution Non-Commercial 4.0 (CC BY-NC 4.0) license, which permits unrestricted use, distribution, and reproduction in any medium provided the original author and source are credited. The material cannot be used for commercial purposes. 
Indonesia has attempted economic recovery through different schemes but the slow movement in the economy persists and this is in addition to other obstacles being faced by SMEs such as financial limitations $(\mathrm{Ng} \&$ Rezaee, 2015), marketing factors, scarcity of raw material sources, and decreased consumer purchasing power due to lockdown factors and large-scale social distancing (Febrian et al., 2018). These tend to affect their sustainable competitiveness and leads to the inability to survive and subsequent failure (Andri et al., 2020; Heriyanto et al., 2021; Purnomo et al., 2019).

Teece (2007) proposed the building of entrepreneurial processes by companies based on capabilities and resources considered difficult to imitate to create competitiveness. This is related to the economic crisis being experienced in different countries and the business environment observed to be running through the digital economy era, thereby, making traditional competitive advantage strategies such as cost leadership, market differentiation, and niche orientation to be inappropriate (Porter, 1980b).

Previous studies have recommended the adoption of unique capabilities and resources as a key factor to ensure sustainable competitive advantage (Febrian et al., 2018; Heriyanto et al., 2021). This, therefore, shows competitive advantage has become a global trend in the $21 \mathrm{st}$ century and a new paradigm capable of resolving economic (Nenzhelele, 2015), environmental (Handoko et al., 2020), and social interests in different countries (Baumgartner \& Ebner, 2010).

The study of competitive advantage continues to evolve as the scope of research develops and this makes providing a brief overview and determining its network important. New methodologies to conduct research involving the use of secondary studies to determine the state of the art (B. Kitchenham et al., 2009; Petersen et al., 2008) and latest research trends have emerged due to the advancement of information technology
(Kuratko, 2010; Qosasi et al., 2019). Moreover, every academician has a role in supporting SMEs to survive obstacles, and the general trend towards evidence-based competitive advantage strategies is expected to lead to an increasing focus on new empirical research methods using systematic mapping studies (Banaeianjahromi \& Smolander, 2016b; Kitchenham \& Charters, 2007; Kitchenham et al., 2009; Rizal, Maulina, Purnomo, \& Febrian, 2017).

Systematic Mapping Studies (SMS) is one of the secondary study methods which is getting a lot of attention lately. It aims to explore existing scientific publications and examines the contents in depth from several perspectives. This method has more benefits than the typical literature review in other literary methods due to its ability to reduce bias, recognize a broader research context, and enable the production of new research maps (Rizal et al., 2017).

SMS is able to determine the state-of-theart from existing research and also provides a map of current literature to produce useful findings for use in real life and for academics to identify future research gaps (Akkermans et al., 2003). Several literature studies related to competitive advantage have, however, been conducted in Indonesia (Ardyan et al., 2017; Ginting, 2015; Handayani et al., 2013; Hoque et al., 2016; Lukiastuti et al, 2017; Munizu, 2013; Ong \& Ismail, 2012; Roostika et al., 2015; Rufaidah, 2016; Budiarto et al., 2017; Samsir et al., 2017; Sulistyo \& Siyamtinah, 2016; Susanti \& Arief, 2015; Tjahjaningsih et al., 2017; Widodo \& Shahab, 2015) but only a few discussed the systematic mapping method.

The purpose of this research was to conduct initial research on SMS to build a further system. This involved the use of Scopus electronic database to retrieve articles on competitive advantage in the SMEs field and 1,435 publications were analyzed based on the following Research Questions (RQ):

1. RQ1. What is the focus and locus of research on the topic being studied? 
2. RQ2. What are the paper type and research method used?

3. RQ3. How did the topic develop in each country over time?

\section{Methodology}

This paper uses a Systematic Mapping Study (SMS) which is rooted in a popular literature review study in medical research. SLR aims to find, identify, evaluate, classify, and interpret all available and relevant literature related to the defined research questions. The Systematic Mapping Study (SMS) method was adapted and applied to Competitive Advantage in SMEs to review and analyze all current and applicable sources of literature relevant to the study issues found (Banaeianjahromi \& Smolander, 2016a; Escandón-Barbosa, Hernandez-Espallardo, \& Rodriguez, 2016; Kitchenham, 2004; Rizal et al., 2017). The most common reason for conducting systematic reviews is to summarize the empirical proof on the desired topic.

Then, it identifies gaps in current research and provides suggestions for future observations, therefore it will provide a preliminary basis for new research (Kitchenham \& Charters, 2007). The process applied in this study was detailed while some options in the systematic map of Banaeianjahromi \& Smolander (2014) were also discussed.

SMS is known to be a tool for interpreting the description of a given research field (Kitchenham \& Charters, 2007) due to its ability to explore detailed information. The key stages of the procedure include the specification of the study issue, the scanning for appropriate documents, the filtering of articles, the abstract keywording as well as the extraction and mapping of data. Each of these steps has an individual result but the result is used as the systematic map.

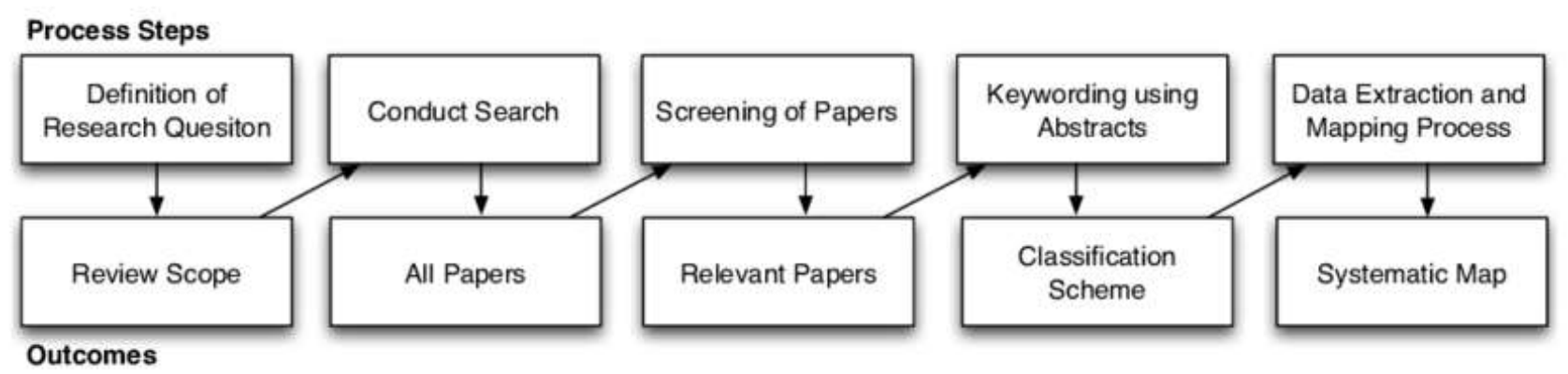

Figure 1. Systematic Mapping Process

\section{Searching Steps}

An online search was conducted on Scopus indexed electronic database accurately as possible to improve the accuracy of the SMS results. This section defines the process to select data sources, specify search strings, and classify exclusion and inclusion criteria and for the purpose of this study, the search process from Petersen et al. (2008) and Banaeianjahromi \& Smolander (2014) was adopted. Moreover, the complete process of
SMS used with reference to the suggestions from Kitchenham (2007) is presented in Figure 2.

Search strings were generated using recommendations from Banaeianjahromi \& Smolander (2016) and Barbosa \& Alves (2011) with the first step being the determination of the main keywords.

The second was to review well-known studies in competitive advantage.

The third was the discovery of alternate types of keywords to be used in the search

Copyright @ 2021 Author(s), published by Vytautas Magnus University. This is an open access article distributed under the terms of the Creative Commons Attribution Non-Commercial 4.0 (CC BY-NC 4.0) license, which permits unrestricted use, distribution, and reproduction in any medium provided the original author and source are credited. The material cannot be used for commercial purposes. 
process. while the final step was to use Boolean operators to synthesize into a single search string.

In mathematics and logic, the arguments and functions of Boolean operators assume the value of the set of two elements (AND/OR). Boolean AND is a Boolean operator which gives the value one if and only if all the operands are one, and otherwise has a value of zero. Boolean OR is a Boolean operator that gives the value one if at least one operand (or input) has a value of one, and otherwise has a value of zero.
Meanwhile, AND or OR Boolean operators were not used in the second stage due to the application of the "search within results" feature in the Scopus search panel with a string "(SMEs OR" small AND medium AND enterprises") in the third stage and 1,643 results were discovered.

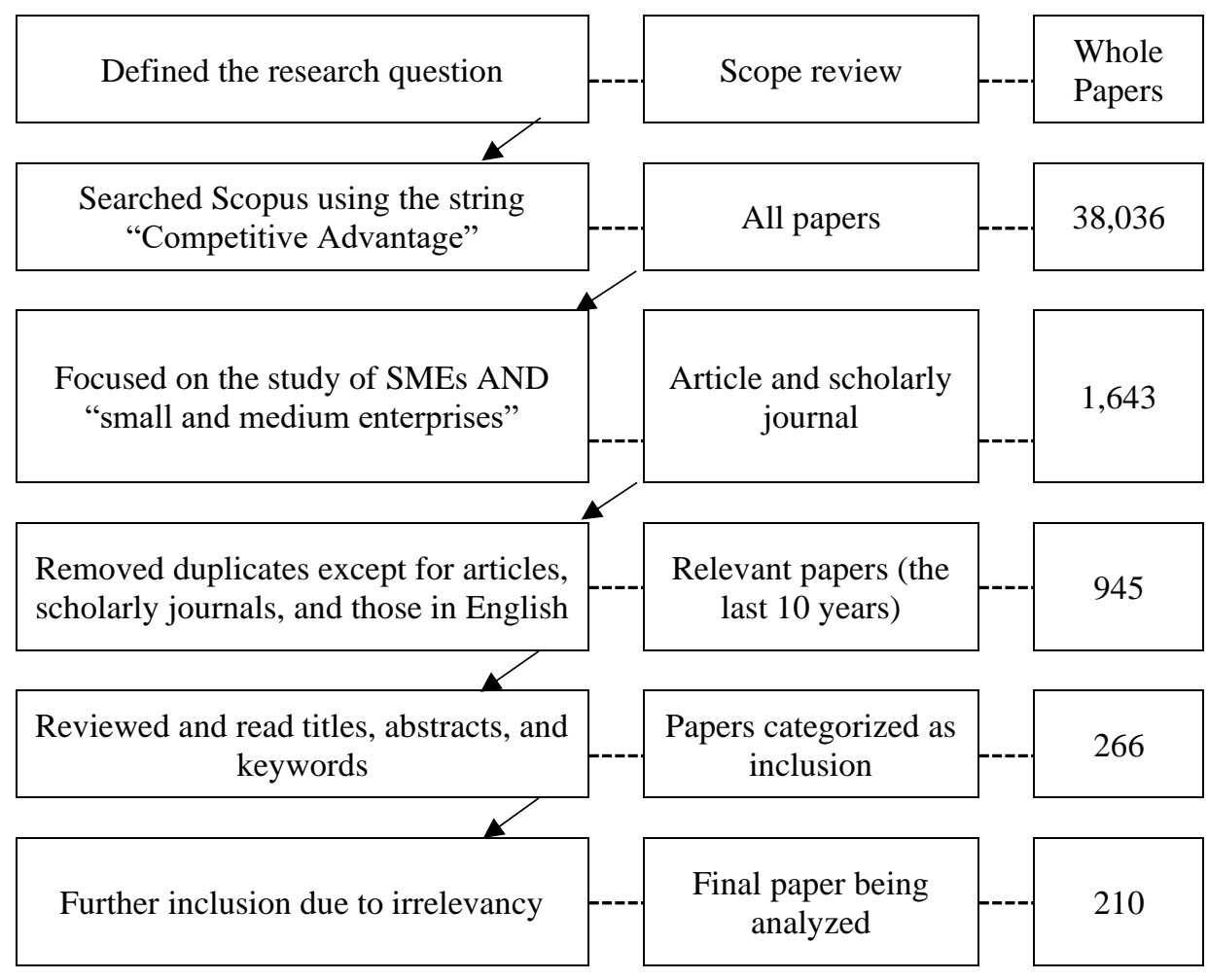

Figure 2. SMS Process (Searching)

The search strings were filtered based on titles, abstracts, and keywords while the types of articles, final publications, source type of journals, use of English, focus on the subject areas of Business, Management, and Accounting in the last 10 years were used to minimize the search.
This was followed by defining the categories of articles to be excluded through the concept of exclusion and inclusion criteria which involves deleting irrelevant articles as a reference to review articles with predetermined topics as classified in the following table. 
Table 1. Inclusion and Exclusion Criteria

\begin{tabular}{ll}
\hline Inclusion & Exclusion \\
\hline 1. The research focusing on & 1. Papers that do not discuss competitive advantage in SMEs \\
competitive advantage in SMEs & 2. In languages other than English \\
2. In English & 3. Dissertation, thesis, book section, material summary, presentation, \\
3. Only articles in scholarly journals & employment report, trade literature, editorial notes, unclear literature \\
of Business, Management, and & 4. Papers that were not peer-reviewed \\
Accounting & 5. Duplicate research \\
4. Peer-reviewed papers &
\end{tabular}

\section{Classification Steps}

In a systematic mapping process, to analyze and classify articles that have been selected based on criteria, we compile a classification scheme that refers to

Banaeianjahromi \& Smolander (2014) and Petersen et al. (2008). The article classification process has been shortened in Figure 2. Inclusion articles are classified into three categories as shown in Table 2. The first category involves articles based on research focus with reference to Petersen et al. (2008), the second defines paper types based on the classifications presented by Wieringa et al. (2006) while the third is based on the research method proposed by Musianto (2002). Table 2 describes the three categories in our classification process.

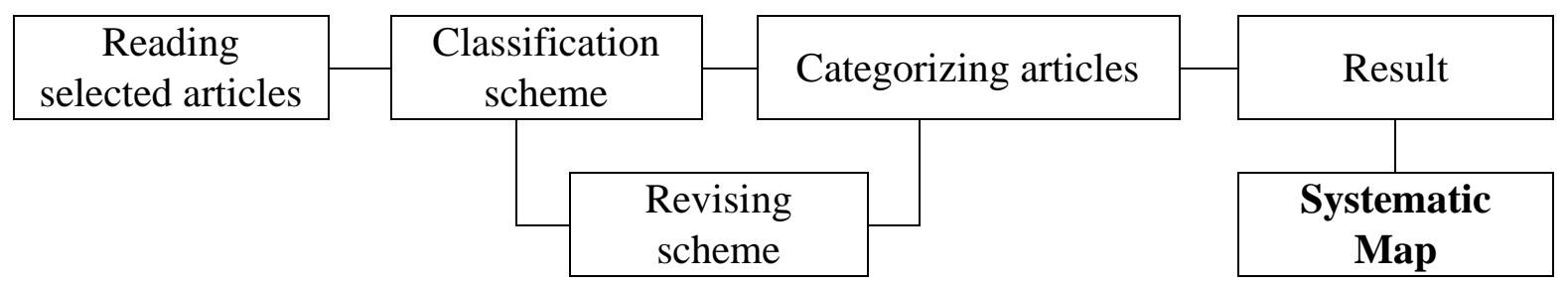

\section{Figure 3. Process of Classification}

Table 2. Classification Category

\begin{tabular}{|l|l|}
\hline Paper Type & Explanation \\
\hline Validation Research & A never been applied modern inquiry method (Experiment/observation) \\
\hline Evaluation Research & The investigation approach is applied and is discussed in the assessment method \\
\hline Solution Proposal & A new/applicable solution or an established approach. \\
\hline Philosophical Paper & The study provides a new outlook on the concept using a taxonomy or logical structure. \\
\hline Methods & Explanation \\
\hline Qualitative Method & $\begin{array}{l}\text { Qualitative Methods include Rapid Assessment Process, secondary data, ethnography, focus } \\
\text { group discussions, in-depth interviews, diaries, and language analysis. }\end{array}$ \\
\hline Quantitative Method & $\begin{array}{l}\text { Quantitative Method includes sample design as well as hypotheses and tests in statistical } \\
\text { formulations. }\end{array}$ \\
\hline Mix Method & $\begin{array}{l}\text { Mix-method research combines qualitative and quantitative approach in its methodology } \\
\text { during the data collection phase and all stages of the research process (Abbas, 2010) }\end{array}$ \\
\hline Research focus & Explanation \\
\hline Environmental Factor & $\begin{array}{l}\text { These are characteristics in the environment affecting the operations and growth of an } \\
\text { organization }\end{array}$ \\
\hline
\end{tabular}

Copyright (C 2021 Author(s), published by Vytautas Magnus University. This is an open access article distributed under the terms of the Creative Commons Attribution Non-Commercial 4.0 (CC BY-NC 4.0) license, which permits unrestricted use, distribution, and reproduction in any medium provided the original author and source are credited. The material cannot be used for commercial purposes. 


\begin{tabular}{|l|l|}
\hline Paper Type & Explanation \\
\hline $\begin{array}{l}\text { Information and } \\
\text { Communication } \\
\text { Technology (ICT) }\end{array}$ & $\begin{array}{l}\text { A terminology covering all technological facilities for the collection and dissemination of } \\
\text { information. It addresses two main fields of information technology and communication } \\
\text { technology. }\end{array}$ \\
\hline $\begin{array}{l}\text { Organizational } \\
\text { capability }\end{array}$ & $\begin{array}{l}\text { The ability of corporate organizations to develop abilities such as skills, experience, and } \\
\text { employee quality to achieve company goals. }\end{array}$ \\
\hline Innovation Capability & The ability to create innovations, new ideas, and new concepts. \\
\hline $\begin{array}{l}\text { Dynamic } \\
\text { Capability }\end{array}$ & $\begin{array}{l}\text { This includes management, research and development, products, manufacturing, human } \\
\text { resources, and organizations. }\end{array}$ \\
\hline Business development & $\begin{array}{l}\text { The development of the company through corporate parenting strategy, marketing strategy, } \\
\text { and other things. }\end{array}$ \\
\hline $\begin{array}{l}\text { Knowledge } \\
\text { Management }\end{array}$ & $\begin{array}{l}\text { A collection of methods, processes and procedures used by people, teams, and organizations } \\
\text { to handle 'knowledge' }\end{array}$ \\
\hline $\begin{array}{l}\text { Entrepreneurial } \\
\text { Orientation }\end{array}$ & This includes dimensions such as autonomy, proactiveness, taking risk, and innovation. \\
\hline $\begin{array}{l}\text { Entrepreneurial } \\
\text { Marketing }\end{array}$ & Marketing activities by new businesses and micro and small enterprises. \\
\hline Investment & Capital support from Bank and Non-Bank financial institutions. \\
\hline
\end{tabular}

\section{Result and discussion}

This segment discusses the effects of the mapping-based research question and 210 articles retrieved on competitive advantage in SMEs were analyzed using the Microsoft Excel 365 application regarding the category, locus, method, type of paper, and development after which 15 types of article documents from Indonesia were found.

\section{Focus and Research License (RQ1)}

To answer RQ1, 210 articles were classified on research focus areas including environmental factors, information, and communication technology (ICT), organizational capability, innovation capability, dynamic capability, business development, knowledge management, entrepreneurial orientation, entrepreneurial marketing, and investment.

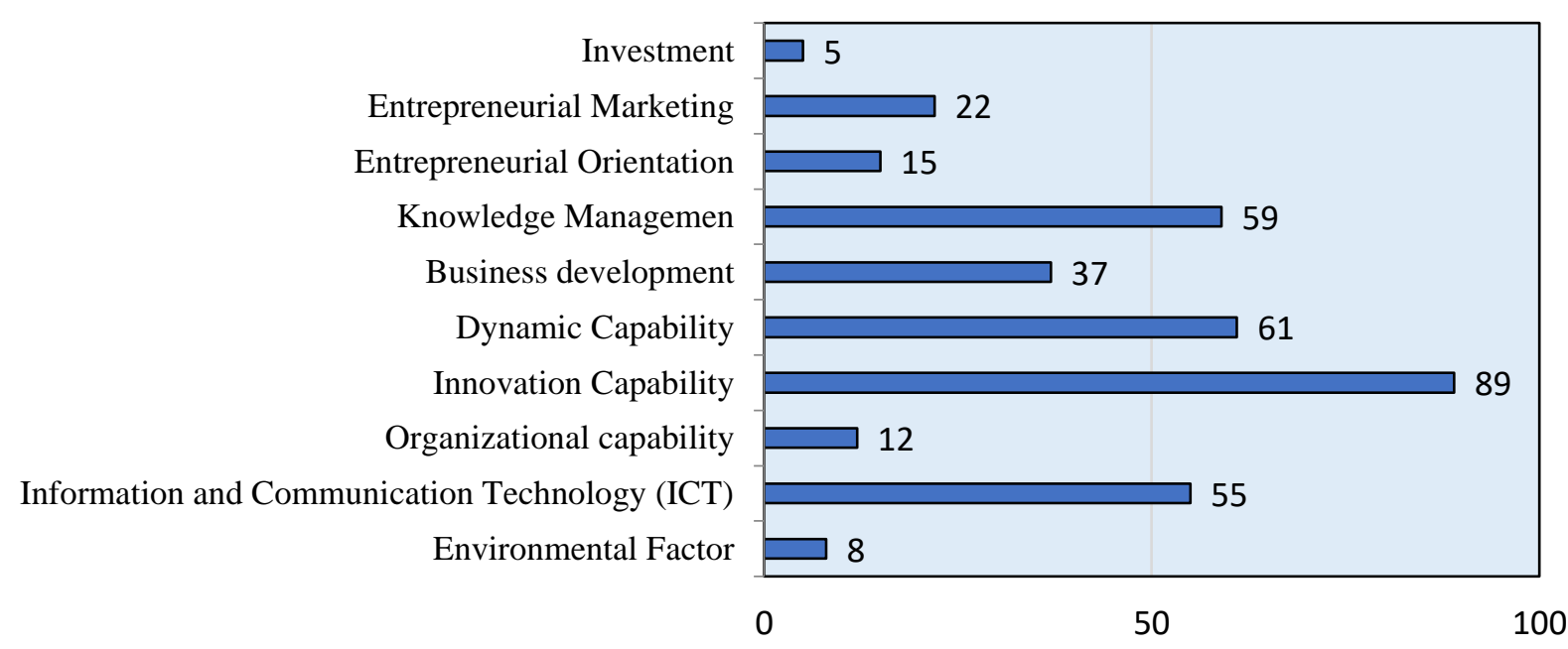

Figure 4. Research Focus (1)

The percentage of the topics studied is presented in Figure 4 with the highest found to be innovation capability at $25 \%$ with 89 papers followed by Dynamic Capability at $17 \%$ with 61 , Knowledge management at $16 \%$ with 59, Information and Communication Technology 
(ICT) at $15 \%$ with 55 while the least was found with environmental factor at $2 \%$, investment at $1 \%$.

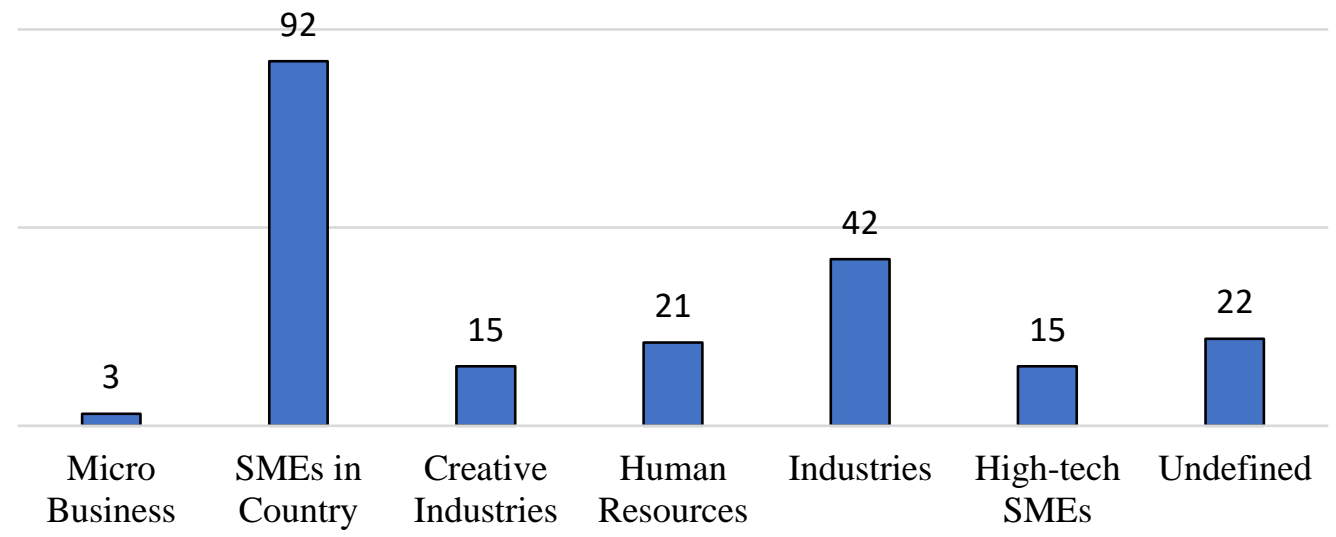

Figure 5. Research Focus (2)

Most of the studies on competitive advantage are focused on SMEs located in a region, both in a city and in a village, as observed from a total of 92 studies, 42 are focused on industries, and 15 on creative industries and High-tech SMEs such as technology companies as indicated in Figure 5. Meanwhile, some of the articles were discovered not to have a research locus in terms of the place being studied and this led to the conclusion that there are several studies which are philosophical.

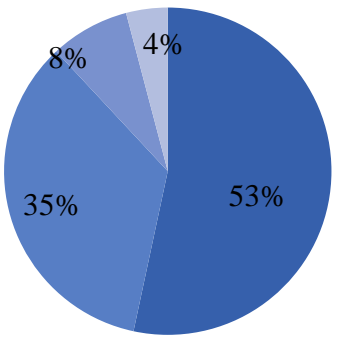

- Validation research

Philosophical paper

- Solution Proposal

Evaluation research

Figure 6. Paper Type

Figure 6 shows the most used paper type is validation research with a total of 143 studies represented by $53 \%$ followed by philosophical papers with 93 represented by $35 \%$, solution proposal with 21 represented by $8 \%$ while the least is the evaluation research with 11 studies which is $4 \%$ of the total.
The research methods were classified according to Musianto (2002) and quantitative, qualitative, and mixed-method approaches were observed to have been used as indicated in Figure 7. The quantitative method was found to be the most common method applied as recorded with $57 \%$ representing 119 studies due to its ability to

Copyright (C 2021 Author(s), published by Vytautas Magnus University. This is an open access article distributed under the terms of the Creative Commons Attribution Non-Commercial 4.0 (CC BY-NC 4.0) license, which permits unrestricted use, distribution, and reproduction in any medium provided the original author and source are credited. The material cannot be used for commercial purposes. 
test and evaluate followed by the qualitative method with $38 \%$ for 80 studies and mixed method with $5 \%$ representing 11 studies.

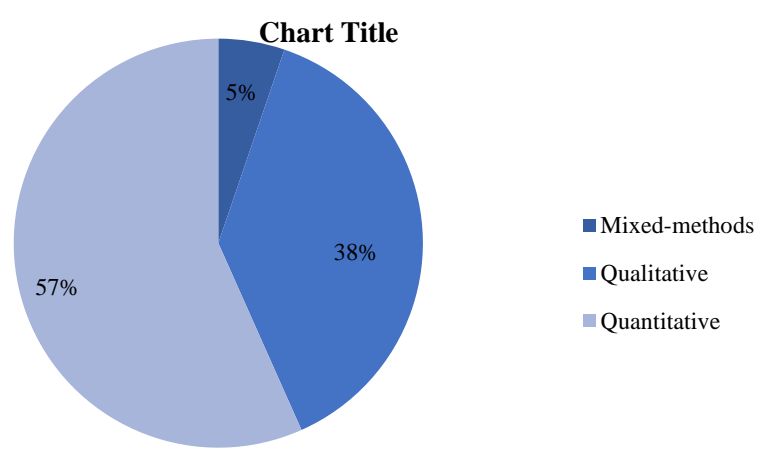

Figure 7. Research Method

The trend of publication in each country over time (RQ3)

The mapping showed the country with the most research on competitive advantage is the United Kingdom with a total of 35 publications followed by Malaysia with 26 publications while an interesting part is the placement of Indonesia in the third position with 17 publications as shown in Figure 8.

40

34

20

17

$\begin{array}{llllllllllllllllllllllllllllllllllll}5 & 5 & 5 & 4 & 4 & 4 & 4 & 4 & 4 & 3 & 3 & 3 & 3 & 3 & 3 & 2 & 2 & 2 & 2 & 2 & 2 & 1 & 1 & 1 & 1 & 1 & 1 & 1 & 1 & 1 & 1 & 1 & 1 & 1 & 1\end{array}$
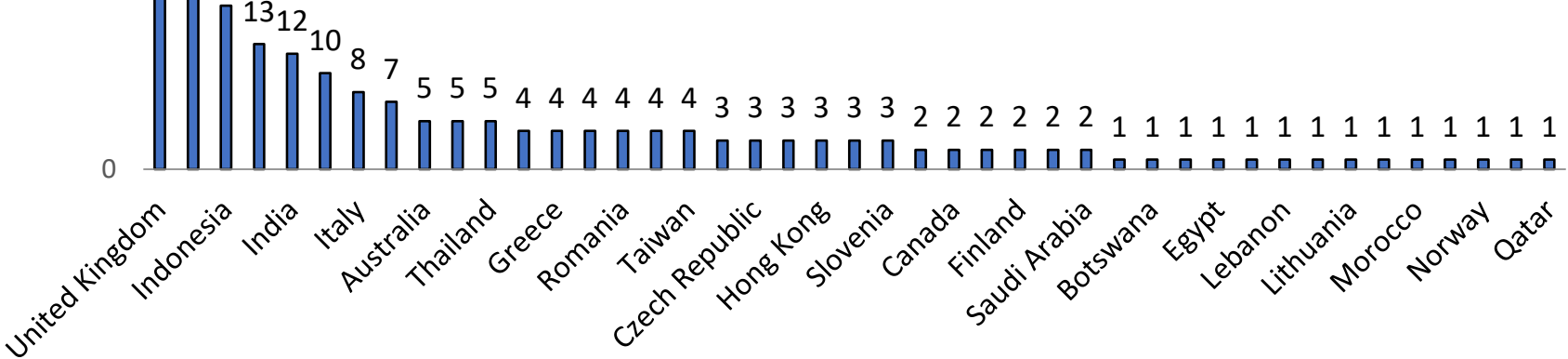

Figure 8. The development of publications in each country

Figure 9 shows the trend of articles published in electronic media databases for a period of ten years starting from 2007 and research on competitive advantage began to develop after the publication of research entitled Competitive Strategy by Porter in 1980.
Since then, the view of corporate competitive advantage has been discussed more deeply on the concept resource-based theory of the firm (Penrose, 1959; Wernerfelt, 1984), which is one of the important factors in the field of strategic management. 


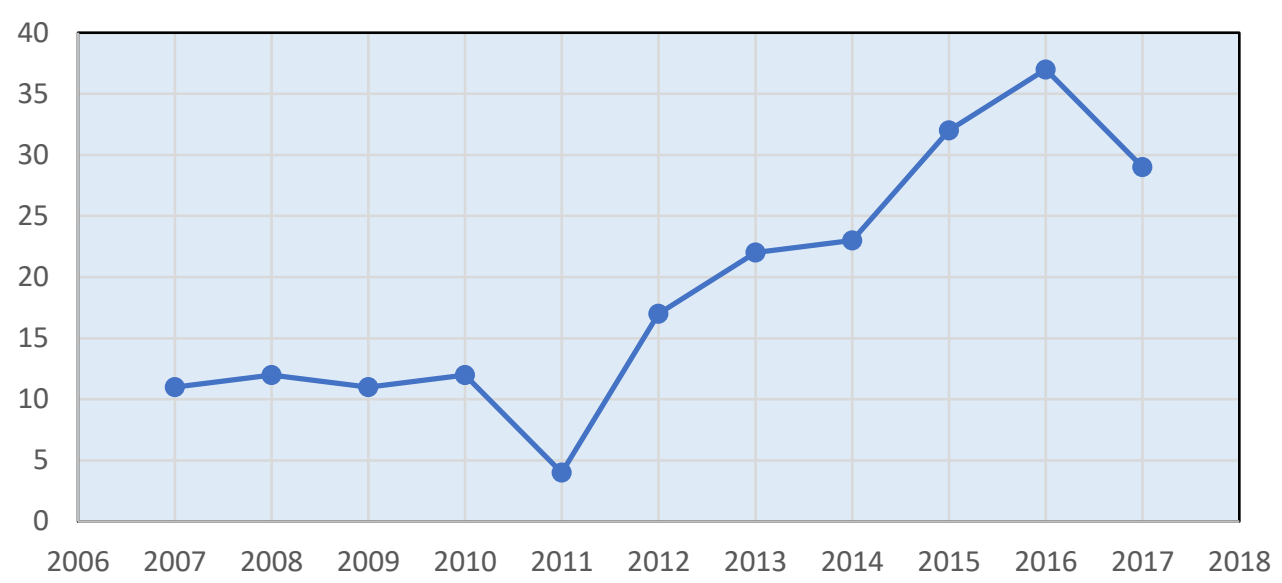

Figure 9. The development of publications over the years

In the early 1980s, Michael Eugene Porter introduced the idea of a strategic group and structure-conduct-performance to create a firm's competitive advantage (Porter, 1979, 1980a, 1985). Porter's thinking contributed to strategic management until Wernerfelt and Barney introduced the Resources-Based Theory of the Firm (RBV). RBV is considered as a new perspective in strategic management (Wernerfelt, 1984). This perspective emphasizes the internal company as a source of competitive advantage in a company (Alvarez \& Barney, 2007; Barney, 2001; Eshima \& Anderson, 2017).

\section{Conclusions and discussion}

The concept of strategic management has evolved because there have been external changes that have resulted in changes in business processes and consumer behavior in the future (Baumgartner \& Ebner, 2010; Chaiprasit \& Swierczek, 2011; Eshima \& Anderson, 2017). Starting from Penrose pioneering the theory of competitive advantage in his scientific publication entitled The Theory of the Growth of the Firm, and until other researchers appeared such as Michael Porter (1979:1980;1985), Wernerfelt (1984), Stalk (1988), Ansoff (2005), Covin \& Slevin (1989), Freeman (1984), Rumelt, Schendel, \& Teece (1991), Teece et al. (1997) and other researchers who have conducted research on competitive advantage and continue to emerge new research today.

In the 1980s and early 1990s, the focus of research shifted from external competitive advantage to a focus on the internal aspects of the company (Barney, 1991; Peteraf, 1993; Prahalad \& Hamel, 1990; Stalk, 1988; Wernerfelt, 1984). This is different from the research conducted by Porter $(1979,1980,1990)$ which analyzed competitive advantage based on external aspects and was not too focused on the internal aspects of the company. Based on the results of the SMS, the research focus that is most studied is innovation capabilities, dynamic capabilities, knowledge management, Information and Communication Technology (ICT), then environmental factors and investment. It was mostly researched from the early 2010 s until it continued to increase in 2017 to 2020 . Today, the development of competitive advantage research is shifting towards a more critical direction. Researchers have recently found that collaboration or business alliances are more important than conventional competitive advantages because they are not in line with current technological developments.

In this study, we conducted a literature study using the SMS method to see the research trends of competitive advantage in the last 10 years. Figure 4 shows the development of research topics that have been widely researched in competitive advantage research studies. Based on the data obtained, most of the research topics regarding the capabilities and resources of the company were carried out. This is in accordance with technological developments and consumer behavior who have switched to digital technology. Even artificial intelligence, robots, and automation of production machines have become a necessity for companies today. Future researchers will have the opportunity to examine 
more deeply the relationship between technology, competencies, capabilities, and scarce resources as an antecedents and consequences of competitive advantage. But the challenge is the uncertainty of the business environment, especially since 2020 is a time of economic downturn for all countries, and will they rise in the tens and come back after the Covid-19 pandemic? or even new challenges such as changing marketing methods and changing business processes?

Scientific journals have become one of the most important processes for sustainable knowledge transfer. Scientific journals are a great place to discuss the latest findings. Due to the fast dissemination of information, scientific journals have more types such as validation research, evaluation research, philosophical and proposed solutions.

In fact, the number of scientific journals continues to increase, and most new scientists are emerging, the study and analysis of scientific journals are needed to find a state of art and novelty in future research.

This article provides a bibliographic overview of research published in Scopus over the past 10 years, starting from the data collected from Scopus and using bibliometric indicators. The results showed that the study of competitive advantage had gone through different stages.

The first phase of 2006 has captured a period in which the number of publications and their impact on the scientific community was low but by 2011 the amount of research interest in competitive advantage dropped dramatically. The second stage (2011-2018) is a period where the number of publications from journals increases rapidly. Since 2011, the results have changed greatly.

The application of competitive advantage is needed to increase the competitiveness of Small and Medium Enterprises (SMEs) because there are millions of competitors who are a real threat and with the ability to close these businesses. This is also necessary because economic growth which is rooted in the resilience of the business world has encouraged several academics, practitioners, research institutions, and the government to develop studies related to competitive advantage through relationships with business actors, companies, and industry.

Several articles on competitive advantage available in the Scopus scientific database are mapped to provide an up-to-date literature review of concepts for ensuring SMEs survival in a competitive business environment. The process involves the application of systematic mapping to determine the concentration areas analyzed and the findings show:

1. The topics studied are broadly focused on Innovation Capability with 25\%, Dynamic Capability with $17 \%$, Knowledge Management with $16 \%$, and Information and Communication Technology with $15 \%$ while small and medium enterprises with $44 \%$.

2. The type of articles most often used is validation research with a total of 143 articles, namely $53 \%$ of the total number of articles, while the methodology most often used is the quantitative approach of $57 \%$.

3 . The country with the highest competitive advantage research in England with 35 publications followed by Malaysia with 26 publications, and Indonesia with 17 publications.

The SMS method is a literature review technique to identify suitable topics to study and select appropriate subject areas and the result is a map of future research that can provide a view for researchers to design future research by exploring the limitations of research. Then, new researchers will easily find antecedents and consequences of competitive advantage studies in the future. 


\section{References}

Akkermans, H. A., Bogerd, P., Yücesan, E., \& Van Wassenhove, L. N. (2003). The impact of ERP on supply chain management: Exploratory findings from a European Delphi study. European Journal of Operational Research.

Alvarez, S. A., \& Barney, J. B. (2007). The entrepreneurial theory of the firm. Journal of Management Studies, 44(7), 1057-1063.

Andri, S., Arifin, K., \& Febrian, A. F. (2020). The influence of ict capability on competitive advantage of small businesses through entrepreneurial orientation and organisational agility-the case of apparel retailers in Pekanbaru Indonesia. International Journal of Innovation, Creativity and Change.

Ansoff, H. I. (2005). Strategic Management. Management, 29, 1-56.

Ardyan, E., Nurtantiono, A., Istiyanto, B., \& Rahmawan, G. (2017). Green innovation capability as driver of sustainable competitive advantages and smes marketing performance. International Journal of Civil Engineering and Technology, September.

Banaeianjahromi, N., \& Smolander, K. (2014). The Role of Enterprise Architecture in Enterprise Integration a Systematic Mapping. European, Mediterranean \& Middle Eastern Conference on Information Systems 2014 (EMCIS2014), 2014, 1-22.

Banaeianjahromi, N., \& Smolander, K. (2016a). What do we know about the role of enterprise architecture in enterprise integration? A systematic mapping study. Journal of Enterprise Information Management, 29(1), $140-164$.

Banaeianjahromi, N., \& Smolander, K. (2016b). Understanding obstacles in Enterprise Architecture Development. ECIS, ResearchPaper7.

Barbosa, O., \& Alves, C. (2011). A Systematic Mapping Study on Software Ecosystems. Proceedings of the Workshop on Software Ecosystems 2011.

Barney, J. (1991). Firm Resources and Sustained Competitive Advantage. Journal of Management, 17(1), 99120.

Barney, J. B. (2001). Resource-based theories of competitive advantage: A ten- year retrospective on the resource-based view. Journal of Management, 27, 643-650. https ://doi.org/10.1177/014920630102700602

Baumgartner, R. J., \& Ebner, D. (2010). Corporate sustainability strategies: Sustainability profiles and maturity levels. Sustainable Development, 18(2), 76-89. https://doi.org/10.1002/sd.447

Chaiprasit, S., \& Swierczek, F. W. (2011). Competitiveness, globalization and technology development in Thai firms. Competitiveness Review: An International Business Journal Incorporating Journal of Global Competitiveness, 21(2), 188-204. https://doi.org/10.1108/10595421111117461

Covin, J. G., \& Slevin, D. P. (1989). Strategic management of small firms in hostile and benign environments. Strategic Management Journal, 10(1), 75-87. https://doi.org/10.1002/smj.4250100107

Escandón-Barbosa, D., Hernandez-Espallardo, M., \& Rodriguez, A. (2016). International Market Orientation and International Outcomes. Global Economy Journal, 16(4), 669-696. https://doi.org/10.1515/gej-2015-0037

Eshima, Y., \& Anderson, B. S. (2017). Firm growth, adaptive capability, and entrepreneurial orientation. Strategic Management Journal, 38(3), 770-779.

Febrian, A. F., Maulina, E., \& Purnomo, M. (2018). The influence of social capital and financial capability on sustainable competitive advantage through entrepreneurial orientation: Empirical evidence from Small and Medium Industries in Indonesia using PLS-SEM. Advances in Social Sciences Research Journal, 5(12).

Freeman, R. E. (1984). Strategic management: A stakeholder approach. In Freeman Edward (Vol. 1).

Ginting, G. (2015). Network Resources as a Key Determinant of Small Medium Enterprises/Smes Export Performance (Case: Creative Industry in Indonesia). International Journal of Applied Business and Economic Research, 15(7), 4867-4886.

Handayani, P. W., Hidayanto, A. N., \& Budi, I. (2013). Business Process Requirements for Indonesian Small Medium Enterprises (SMEs) in Implementing Enterprise Resource Planning (ERP). International Journal of Innovation, Management and Technology, 4(1), 93. https://doi.org/10.7763/IJIMT.2013.V4.366

Handoko, T., Tiyas Tinov, Achmad Fajri Febrian, Risky Arya Putri, Frini Karina Andini, \& Ogi Rifansyah. (2020). Peatlands Restoration As A Potential Solution To Resolve Peatlands Damage Based On Sustainable Development Goals (SDGS) In Sungai Tohor, Indonesia. Jurnal Niara. https://doi.org/10.31849/niara.v13i1.3876

Heriyanto, M., Febrian, A. F., Handoko, T., \& Syofian. (2021). Measurement of natural environment strategy to create an innovation and competitive advantage. Management Science Letters. https://doi.org/10.5267/j.msl.2020.9.015

Hoque, M. R., Saif, A. N. M., AlBar, A. M., \& Bao, Y. (2016). Adoption of information and communication

Copyright (C) 2021 Author(s), published by Vytautas Magnus University. This is an open access article distributed under the terms of the Creative Commons Attribution Non-Commercial 4.0 (CC BY-NC 4.0) license, which permits unrestricted use, distribution, and reproduction in any medium provided the original author and source are credited. The material cannot be used for commercial purposes. 
technology for development: A case study of small and medium enterprises in Bangladesh. Information Development, 32(4), 986-1000. https://doi.org/10.1177/0266666915578202

Kitchenham, B. (2004). Procedures for performing systematic reviews. Keele, UK, Keele University, 33(TR/SE0401), 28.

Kitchenham, B. A. (2007). Kitchenham, B.: Guidelines for performing Systematic Literature Reviews in software engineering. EBSE Technical Report EBSE-2007-01. In EBSE Technical Report.

Kitchenham, B., \& Charters, S. (2007). Guidelines for performing Systematic Literature Reviews in Software Engineering. Engineering, 2, 1051. https://doi.org/10.1145/1134285.1134500

Kitchenham, B., Pearl Brereton, O., Budgen, D., Turner, M., Bailey, J., \& Linkman, S. (2009). Systematic literature reviews in software engineering - A systematic literature review. In Information and Software Technology (Vol. 51, Issue 1, pp. 7-15). https://doi.org/10.1016/j.infsof.2008.09.009

Kuratko, D. F. (2010). Corporate Entrepreneurship: An Introduction and Research Review. In Handbook of Entrepreneurship Research (pp. 129-163). https://doi.org/10.1007/978-1-4419-1191-9_6

Lukiastuti, F., Sutanto, H. A., \& Imaningati, S. (2017). Self-Reliance Improvement Model for Women Batik SMEs. Advanced Science Letters, 23(8), 7309-7313.

Maslakhah, M. (2017). Peran Pemerintah Dalam Meningkatkan Daya Saing Umkm (Studi Pada Pengrajin Logam Pisau Di Desa Hadipolo Kecamatan Jekulo Kabupaten Kudus). STAIN Kudus.

Munizu, M. (2013). The Impact of total quality management practices towards competitive advantage and organizational performance: Case of fishery industry in South Sulawesi Province of Indonesia. Pakistan Journal of Commerce and Social Sciences, 7(1), 184.

Musianto, L. S. (2002). Perbedaan pendekatan kuantitatif dengan pendekatan kualitatif dalam metode penelitian. Jurnal Management Dan Kewirausahaan. https://doi.org/10.9744/jmk.4.2.pp. 123-136

Nenzhelele, T. E. (2015). The impact of business type and sector, location and annual turnover on competitive intelligence practice of small and medium-sized enterprises. Risk Governance and Control: Financial Markets and Institutions, 5(4CONT1), 139-149. https://doi.org/10.22495/rgcv5i4c1art3

Ng, A. C., \& Rezaee, Z. (2015). Business sustainability performance and cost of equity capital. Journal of Corporate Finance.

Ong, J. W., \& Ismail, H. Bin. (2012). Competitive advantage and firm performance: evidence from small and medium enterprises. International Journal of Business and Globalisation, 9(2), 195. https://doi.org/10.1504/IJBG.2012.048960

Penrose, E. (1959). Theory of the growth of the firm. In Theory of the Growth of the Firm.

Peteraf, M. A. (1993). The cornerstones of competitive advantage: A resource-based view. Strategic Management Journal, 14(3), 179-191. https://doi.org/10.1002/smj.4250140303

Petersen, K., Feldt, R., Mujtaba, S., \& Mattsson, M. (2008). Systematic mapping studies in software engineering. EASE'08 Proceedings of the 12th International Conference on Evaluation and Assessment in Software Engineering, $68-77$.

Porter, M. E. (1979). The Structure within Industries and Companies' Performance. The Review of Economics and Statistics, 61(2), 214-227. https://doi.org/Article

Porter, M. E. (1980a). Competitive strategy: Techniques for analyzing industries and competition. New York, 300.

Porter, M. E. (1980b). Competitive Strategy. In Techniques for Analyzing Industries and Competitors : with a New Introduction.

Porter, M. E. (1985). Competitive Advantage. In Competitive Advantage: Creating and Sustaining Superior Performance (Vol. 15, pp. 1-30). https://doi.org/10.1182/blood-2005-11-4354

Porter, M. E. (1990). Competitive Advantage of Nations. Competitive Intelligence Review, 1(1), 14-14.

Prahalad, C. K., \& Hamel, G. (1990). The Core Competencies of the Corporation. Harvard Business Review, 68(3), 79-91. https://doi.org/100-003-757

Purnomo, M., Permana, E., Qosasi, A., Febrian, A. F., \& Miftahuddin, A. (2019). Entrepreneurial Orientation in Micro and Small Enterprises of Traditional Food Centers in Bandung, West Java. Binus Business Review, 10(3).

Qosasi, A., Maulina, E., Purnomo, M., Muftiadi, A., Permana, E., \& Febrian, A. F. (2019). The Impact of Information and Communication Technology Capability on the Competitive Advantage of Small Businesses. International Journal of Technology, 10(1), 167. https://doi.org/10.14716/ijtech.v10i1.2332

Rizal, M., Maulina, E., Purnomo, M., \& Febrian, A. F. (2017). Electronic Road Pricing (ERP): A Systematic Mapping Study. IRCEB.

Roostika, R., Wahyuningsih, T., \& Haryono, S. (2015). the Impacts of External Competitiveness Factors in the 
Handicrafts Industry. Wpływ Zewnętrznych Czynników Konkurencyjności W Przemyśle Rzemieślniczym., 12(1), 166176.

Rufaidah, P. (2016). IJEM Dynamic Capability in Branding Strategy Development. 10, 183-196.

Rumelt, R. P., Schendel, D., \& Teece, D. J. (1991). Strategic management and economics. Strategic Management Journal.

S. Budiarto, D., Prabowo, M. A., \& Herawan, T. (2017). An integrated information system to support supply chain management \&amp; performance in SMEs. Journal of Industrial Engineering and Management, 10(2), 373.

Samsir, Nursanti, A., \& Zulfadil. (2017). The effect of product innovation as mediation in relationship between knowledge management to competitive advantage (Case study in SME of typical food products of Riau Indonesia). International Journal of Economic Research, 14(2), 217-226.

Stalk, G. (1988). Time--The Next Source of Competitive Advantage. In Harvard Business Review (Vol. 66, Issue 4, pp. 41-51). https://doi.org/Article

Sulistyo, H., \& Siyamtinah. (2016). Innovation capability of SMEs through entrepreneurship, marketing capability, relational capital and empowerment. Asia Pacific Management Review, 21(4), 196-203. https://doi.org/10.1016/j.apmrv.2016.02.002

Susanti, A. A., \& Arief, M. (2015). The Effect of Dynamic Capability for the Formation of Competitive Advantage to Achieve Firm's Performance (Empirical Study on Indonesian Credit Co-operatives). Advanced Science Letters, 21(4), 809-813.

Teece, D. J. (2007). Explicating dynamic capabilities: The nature and microfoundations of (sustainable) enterprise performance. Strategic Management Journal, 28(13), 1319-1350. https://doi.org/10.1002/smj.640

Teece, D. J., Pisano, G., \& Shuen, A. (1997). Dynamic capabilities and strategic management. Strategic Management Journal, 18(7), 509-533. https://doi.org/10.1002/(SICI)1097-0266(199708)18:7<509::AIDSMJ882>3.0.CO;2-Z

Tjahjaningsih, E., Handayani, D., Rozak, H. A., \& Santosa, D. B. (2017). Creative technique strategy based on the technique of Tie Dye and Smock using natural colouring to improve the performance of the craftsmen of written batik in Semarang. International Journal of Economic Research, 14(12), 91-103.

UTAMA, D. D. T., \& DARWANTO, D. (2013). Pengembangan Usaha Mikro Kecil dan Menengah (UMKM) Berbasis Ekonomi Kreatif di Kota Semarang. Fakultas Ekonomika dan Bisnis.

Wernerfelt, B. (1984). Consumers with differing reaction speeds, scale advantages and industry structure. European Economic Review, 24(2), 257-270.

Widodo, \& Shahab, M. A. (2015). The model of human capital and knowledge sharing towards sustainable competitive advantages. 13(4), 124-134.

Wieringa, R., Maiden, N., Mead, N., \& Rolland, C. (2006). Requirements engineering paper classification and evaluation criteria: A proposal and a discussion. Requirements Engineering, 11(1), 102-107.

Copyright (C) 2021 Author(s), published by Vytautas Magnus University. This is an open access article distributed under the terms of the Creative Commons Attribution Non-Commercial 4.0 (CC BY-NC 4.0) license, which permits unrestricted use, distribution, and reproduction in any medium provided the original author and source are credited. The material cannot be used for commercial purposes. 